\title{
Reduction of arthritis following intra-articular administration of an adeno-associated virus serotype 5 expressing a disease- inducible TNF-blocking agent
}

\author{
J Adriaansen, M Khoury, C J de Cortie, F J Fallaux, P Bigey, \\ D Scherman, D J Gould, Y Chernajovsky, F Apparailly, C Jorgensen, \\ M J B M Vervoordeldonk, P P Tak
}

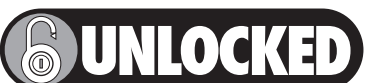

This paper is freely available online under the BMJ Journals unlocked scheme, see http://ard.bmi.com/info/unlocked.dtl
See end of article for authors' affiliations

Correspondence to: Paul P Tak, MD, PhD Academic Medical Center, Div. of Clinical Immunology \& Rheumatology,

Meibergdreef 9, Room F4218, 1105 AZ Amsterdam, The Netherlands; p.p.tak@ amc.uva.nl

Accepted 9 March 2007 Published Online First 15 March 2007

\begin{abstract}
Background: In the context of preclinical development, we studied the potential of intra-articular gene delivery using a recombinant adeno-associated virus 5 (rAAV5) encoding a chimeric human tumour necrosis factor $\alpha(T N F \alpha$ ) soluble receptor I linked to a mouse immunoglobulin heavy chain Fc portion (TNF receptor I; TNFRI-lg).

Methods: Expression was under control of a nuclear factor kappa $B(N F \kappa B)$-responsive promoter and compared with a cytomegalovirus (CMV) promoter (rAAV5.NFKB-TNFRI-lg and rAAV5.CMV-TNFRI-lg, respectively).

Results: Fibroblast-like synoviocytes transduced in vitro with rAAV5.NFKB-TNFRI-lg were able to produce TNFRI-lg protein in response to several stimuli, and this was inhibited upon treatment with a specific NFKB blocking agent. A bioassay revealed that the synthesised TNFRI-Ig was bioactive, showing a higher affinity for human than for rat TNF $\alpha$. Transcription of the transgene and protein production were detectable in joints injected with both constructs. No dissemination of the vector was observed outside the joints. A significant reduction in paw swelling was seen in rats treated with rAAV5.NFKB-TNFRI-Ig. This clinical effect was accompanied by a decrease in pro-inflammatory cytokine levels and an increase in IL10 expression in the synovium.

Conclusion: These results provide evidence that intra-articular gene therapy using rAAV5 encoding TNFRI-Ig may be a safe and feasible approach for the treatment of rheumatoid arthritis. The higher affinity for human TNF $\alpha$ suggests that in patients with rheumatoid arthritis the therapeutic effect might be even more pronounced than in rat adjuvant arthritis.
\end{abstract}

$\mathrm{R}$ heumatoid arthritis is a chronic immune-mediated disease characterised primarily by inflammation of the joints with concomitant destruction of both cartilage and bone ${ }^{1}$ Besides conventional therapy with disease-modifying antirheumatic drugs, novel approaches aimed at TNF $\alpha$ blockade have successfully entered clinical practice. It is now possible to reach 20\% improvement (by American College of Rheumatology (ACR) criteria) in $>60 \%$ of patients with rheumatoid arthritis treated with tumour necrosis factor (TNF)-blocking agents. ${ }^{2} 3$

Most of these ACR-20\% responders, however, will still have some actively inflamed joints, and long-term systemic treatment with anti-TNF agents can result in serious adverse effects. ${ }^{4}$ Importantly, some patients have only a few symptomatic joints and are not considered candidates for receiving systemic anti-TNF therapy. Local gene transfer might allow persistent production of a TNF inhibitor within the inflamed joint directly, and enhance the bioavailability at the site of inflammation when the right vector is used.

Recombinant adeno-associated viruses (rAAV) are currently considered the most suitable vectors for gene therapy in chronic diseases because of their safety profile. ${ }^{5}$ These vectors are not pathogenic in humans, show expanded tropism and are able to establish long-term production of the transgenic protein in animal models of arthritis. ${ }^{67}$ The therapeutic potential of rAAV expressing a TNF inhibitor has previously been demonstrated in two animal models of arthritis. Intra-articular injection of rAAV type 2 (rAAV5) encoding the p55 TNF receptor (TNFR) in the joints of human TNF $\alpha$ transgenic mice decreased arthritis activity. ${ }^{8}$ A similar effect was shown in rats with arthritis induced by streptococcal cell wall after administration of an rAAV2 vector containing the rat p75TNF receptor-immunoglobulin FC (TNFR:Fc) fusion gene. ${ }^{9}$ In a recent study it was shown that rAAV type 5 (rAAV5) may be superior in transducing rodent arthritic synovium compared with rAAV2, without inducing a significant immune response and is, therefore, an excellent candidate vector for synovial gene transfer. ${ }^{10}{ }^{11}$

We combined this promising vector with a chimeric human soluble p55 TNFR-Ig coupled to the Fc part of murine IgGl (TNFRI-Ig) to form the therapeutic gene, placed under control of a disease-inducible nuclear factor kappa B (NFkB) responsive promoter compared with a cytomegalovirus (CMV) immediate early promoter. As we intend to develop intraarticular gene therapy for rheumatoid arthritis, we evaluated the effects of these gene constructs on arthritis activity, cytokine levels, and the biodistribution after intra-articular injection in the rat adjuvant arthritis model of rheumatoid arthritis.

Abbreviations: ACR, American College of Rheumatology; CMV, cytomegalovirus; Ct, threshold cycle (Ct); DMEM, Dulbecco's modified Eagle's medium; FCS, fetal calf serum; FLS, fibroblast-like synoviocyte; GADPH, glyceraldehyde phosphodehydrogenase; HRP, horseradish peroxidase; IL, interleukin; LPS, lipopolysaccharide; NFKB, nuclear factor kappa B; PDTC, pyrrolidinedithiocarbamate; rAAV, recombinant adenoassociated virus; TNFR, tumour necrosis factor receptor 


\section{METHODS}

\section{Construction of expression vectors}

The chimeric hTNFRI/mIgG gene was obtained and cloned into a pVAX2 plasmid, as described previously. ${ }^{12}{ }^{13}$ This gene was subsequently inserted into a pAAV2-CMV shuttle plasmid (Applied Viromics, Fremont, CA). As control vector, we used the CMV shuttle plasmid without transcription cassette. To obtain an NFKB-driven construct, the CMV promoter was replaced by an NFkB-responsive promoter. All constructs were confirmed by restriction-site analysis and sequencing, and subsequently used for vector production.

\section{Vector production}

Recombinant AAV5 vectors were produced by the vector cores of the University of North Carolina (Chapel Hill, North Carolina, USA), as previously described ${ }^{14}$ and University Hospital of Nantes (France), supported by the Association Française contre les Myopathies, as described previously. ${ }^{15}$

Isolation of human primary fibroblast-like synoviocytes Synovial biopsies from patients with rheumatoid arthritis were enzymatically dispersed and fibroblast-like synoviocytes (FLS) were cultured as described previously. ${ }^{16}$ The cells were used from passages 3 to 10 . The medical ethics committee of the Academic Medical Center, University of Amsterdam, approved the protocol and patients gave written informed consent.

\section{In vitro transduction of fibroblast-like synoviocytes}

FLS were seeded in 48 -wells plates at $3.5 \times 10^{4}$ cells/well in Dulbecco's modified Eagle's medium (DMEM)/10\% fetal calf serum (FCS) (Gibco-BRL, Grand Island, New York, USA). After 24 hours, rAAV5.TNFRI-Ig constructs were added at a multiplicity of infection (MoI) of $2 \times 10^{3}$ in DMEM/10\% FCS. As controls, rAAV5.GFP and a non-expressing rAAV5 vector were used. Medium was replaced the next day and collected 48 hours later. For stimulation experiments, medium with $2 \%$ serum replacement was used (Sigma-Aldrich Corp., St Louis, Missouri, USA). Forty-eight hours after transduction medium was replaced with medium containing $1 \mu \mathrm{g} / \mathrm{ml}$ lipopolysaccharide (LPS), $100 \mathrm{ng} / \mathrm{ml} \mathrm{TNF} \alpha$, or $100 \mathrm{ng} / \mathrm{ml} \mathrm{ILl} \beta$ (R\&D Systems, Minneapolis, Minnesota, USA) in the presence or absence of ammonium pyrrolidinedithiocarbamate (PDTC, $200 \mu \mathrm{M}$ ), a specific inhibitor of NFKB ${ }^{17}$ (Calbiochem, San Diego, California, USA), and harvested after 24 hours.

\section{TNF $\alpha$ neutralising activity in vitro}

A bioassay was performed using TNF $\alpha$-sensitive WEHI-164 subclone 13 cells (adapted from Eskandari et $a^{18}{ }^{18}$ ), to determine TNFR-Ig neutralising capicity. Cells were resuspended at $1 \times 10^{6}$ cells/ml in RPMI-1640/10\% FCS, 2 mmol L-glutamine and $40 \mathrm{mM} \mathrm{LiCl}$, and $50 \mu \mathrm{l} /$ well was dispensed into 96-well culture plates. In parallel, medium from FLS was transduced with rAAV5. NFкB-TNFRI-Ig was incubated in serial dilutions for 1 hour with recombinant rat or human TNF $\alpha(62.5 \mathrm{pg} / \mathrm{ml}$ for human $\mathrm{TNF} \alpha$ and $20 \mathrm{pg} / \mathrm{ml}$ for rat $\mathrm{TNF} \alpha$ ). Recombinant human and rat $\mathrm{TNF} \alpha$ standards $(0.05-500 \mathrm{pg} / \mathrm{ml})$ were used in duplicate in the appropriate wells and incubated at $37^{\circ} \mathrm{C}$ for 20 hours. The cell viability was assessed by addition of $10 \mu \mathrm{l} /$ well of a $5 \mathrm{mg} / \mathrm{ml}$ solution of 3-(4,5-dimethylthiazol-2-yl)2,5diphenyltetrazolium bromide (MTT). Four hours later, plates were centrifuged and medium was discarded, $100 \mu \mathrm{l}$ acidified isopropanol $(0.01 \mathrm{~mol} / \mathrm{l} \mathrm{HCl})$ was added and absorbance was read at $570 \mathrm{~nm}$ using $650 \mathrm{~nm}$ as a reference. The percentage of human or rat TNF $\alpha$ blockade by TNFRI-Ig could be calculated using the corresponding standard curve and was corrected for the amount of TNFRI-Ig protein present in the medium samples.

\section{Local gene transfer}

Pathogen-free male Lewis rats (150-200 g) were obtained (Harlan Sprague Dawley Inc.; Horst, The Netherlands). The animal care and use committee of the University of Amsterdam (Amsterdam, The Netherlands) approved all experiments.

Rats were immunised at the base of the tail with $1 \mathrm{mg}$ of Mycobacterium tuberculosis H37RA (Difco, Detroit, Michigan, USA) in $0.1 \mathrm{ml}$ mineral oil on day $0 .{ }^{19}$ Paw swelling was measured daily by water displacement plethysmometry. The right ankle joints were injected intra-articularly on day 12 after immunisation with $2 \times 10^{10}$ viral molecules of rAAV5.NFkBTNFRI-Ig, rAAV5.CMV-TNFRI-Ig, or empty vector in a total volume of $50 \mu \mathrm{l}$ saline. ${ }^{20}$ Animals were killed 2 weeks later. Hind paws and organs were collected to evaluate biodistribution. The experiments were performed first with 6 animals per group (total of 18) and subsequently using 10 animals per group (total of 30). In both experiments, the groups were divided into two subgroups, one for histology ( 2 or 5 animals, respectively) and one for RNA and protein isolation (4 and 5 animals, respectively). For histology, organs and hind paws were fixed in $10 \%$ formalin, paws were decalcified and subsequently embedded in paraffin wax. For RNA and protein isolation, joints were snap-frozen in liquid nitrogen.

\section{Detection of human TNFRI mRNA by real-time PCR}

Ankle joints and organs were snap-frozen in liquid nitrogen, pulverised, and homogenised in Trizol reagent $(100 \mathrm{mg} / \mathrm{ml})$ (Invitrogen). Total RNA was isolated from the aqueous phase according to the manufacturer's instructions and cDNA was synthesised.

For reverse transcriptase PCR, $5 \mu \mathrm{l}$ of cDNA solution was amplified (AccuPrime SuperMix I; Invitrogen Life Technologies, Carlsbad, California, USA), $215 \mathrm{mmol} / \mathrm{l}$ of the forward TNFRI primer (specific for human TNFRI) ( $5^{\prime}$ TCTACCTAGCAGGCCTCG-3') and $215 \mathrm{mmol} / \mathrm{l}$ of the reverse TNFRI-Ig primer (5'-GGAGCAGCTGAGGCAGTG-3') in a total volume of $50 \mu \mathrm{l}$. Rat glyceraldehyde phosphodehydrogenase (GAPDH) was used as control (forward: 5'-CGGTGTCAACGGATTTGGC-3', reverse: 5'-CCATGCCAGTGAGCTTCCC-3'). Amplification was performed in a thermocycler (Bio-Rad; Veenendaal, The Netherlands) as follows: 3 minutes at $95^{\circ} \mathrm{C}$, 35 cycles of $94^{\circ} \mathrm{C}$ for 1 minute, $59^{\circ} \mathrm{C}$ for 90 seconds and $72^{\circ} \mathrm{C}$ for 1 minute, respectively, followed by a final extension phase at $72^{\circ} \mathrm{C}$ for 10 minutes. The PCR products were analysed by standard agarose gel electrophoresis.

Real-time PCR amplification mixtures contained $25 \mathrm{ng}$ template cDNA, $2 \times$ SYBR Green I Supermix (Bio-Rad) and $300 \mathrm{nmol} / \mathrm{l}$ primers for TNFRI (both rat and human; forward, 5'-CGATTTGCTGTACCAAGTGC-3' and reverse, 5' -TGAGGCAGTGTCTGAGGTG-3'. As an internal reference gene, rat GAPDH was used (forward: 5' -ATGCCATCACTGCCACTC-3', reverse 5' GGGTAGGAACACGGAAGG-3'). Reactions were run on a realtime thermal cycler (MiniOpticon; Bio-Rad). The thermal profile consisted of 1 cycle at $95^{\circ} \mathrm{C}$ for 3 minutes, 40 cycles at $95^{\circ} \mathrm{C}$ for 15 seconds, and at $59^{\circ} \mathrm{C}$ for 45 seconds. Each assay included (in duplicate): a standard curve of five serial dilutions of TNFRI and GAPDH cDNA, a no-template control and $25 \mathrm{ng}$ of sample cDNA. Each run was followed by a melting curve. Single-control normalisation for internal control gene and correction for primer efficiency were calculated as described earlier. $^{21}$

\section{Detection of human TNFRI-Ig and rat TNF $\alpha$ by sandwich ELISA}

Protein was isolated from crushed joints by adding $2 \mathrm{ml}$ of lysis buffer $(20 \mathrm{mmol} / \mathrm{l}$ HEPES, $0.5 \mathrm{~mol} / \mathrm{l} \mathrm{NaCl}, 0.25 \%$ Triton $X$ and protease inhibitors) to $200 \mathrm{mg}$ pulverised ankle joint, mixed by 
rotations for 4 hours at $4^{\circ} \mathrm{C}$ and then spun in a centrifuge. The amount of protein was detected in supernatants. The levels of human TNFRI-Ig or rat TNF $\alpha$ in the medium and joint isolates were quantified according to the manufacturer's protocol (Duoset; R\&D systems).

\section{Joint histology}

Arthritic paws were fixed in $10 \%$ buffered formalin, and decalcified in $15 \%$ EDTA. The paws were then embedded in paraffin and $5 \mu \mathrm{m}$ sagittal serial sections of the ankle joints were cut. Tissue sections were stained with haematoxylin and eosin. The tissue was evaluated using a semiquantative scoring system (0-4) for synovial hyperplasia as described previously. ${ }^{22}$

\section{Immunohistochemistry}

Paraffin wax-embedded sections $(5 \mu \mathrm{m})$ were dewaxed and rehydrated in a gradient of alcohol, and endogenous peroxidase activity was inhibited using $0.1 \%$ sodium azide and $0.3 \%$ hydrogen peroxide in phosphate-buffered saline. Antigen retrieval was performed by heating the sections 10 minutes at $121^{\circ} \mathrm{C}$ in $0.1 \mathrm{~mol} / \mathrm{l}$ citric acid $\mathrm{pH}$ 6.0. Primary IgG antibodies (goat anti-human TNFRI, goat anti-rat TNF $\alpha$, goat anti-rat interleukin (IL) $1 \beta$, goat anti-rat IL10, and goat anti-rat IL6; R\&D Systems) were incubated overnight at $4^{\circ} \mathrm{C}$, followed by incubation with horseradish peroxidase (HRP)-conjugated swine anti-goat immunoglobulin (Tago, Burlingame, California, USA) for 30 minutes. For control sections, the primary antibodies were omitted or an irrelevant antibody was used. Enhancement of the signal was performed with biotinylated tyramide (NEN Life Science Products, Boston, Massachusetts, USA) and HRP-conjugated streptavidin (Dako, Hamburg, Germany) for 15 minutes. ${ }^{23}$ HRP activity was detected using hydrogen peroxide as substrate and 3-amino9-ethylcarbazole (Sigma) as chromogen. Sections were briefly counterstained with Mayer's haemalum solution and mounted in Kaiser's glycerol gelatin (Merck, Darmstadt, Germany).

\section{Microscopy analysis}

After immunohistochemical staining, the various markers in the synovial tissue of the ankle joints were scored semiquantitatively on a 5 -point scale $(0$, minimal expression; 4 , abundant expression of a marker). All sections were analysed in a blinded manner by two independent observers. Minor differences between the observers were resolved by mutual agreement. ${ }^{24}$

\section{Statistics}

Differences between groups were determined by KruskalWallis test, followed by a Mann-Whitney U rank sum test. A $\mathrm{p}$ value $<0.05$ was considered statistically significant. All analyses were done using SPSS version 11.5 (SPSS, Chicago, Illinois, USA).

\section{RESULTS}

\section{In vitro validation of TNF $\alpha$ blocking rAAV 5 constructs}

To test whether FLS, the main target cells for rAAV5 in vivo, were able to produce TNFRI-Ig after rAAV5 transduction and if this production was responsive to NFKB after activation with inflammatory stimuli, we infected FLS with either rAAV5.NFKB-TNFRI-Ig or rAAV5.CMV-TNFRI-Ig vectors. The cells were stimulated with TNF $\alpha$, IL1 $\beta$ or LPS in the presence or absence of the specific NFKB blocking agent PDTC (figure lA). As control for transduction efficacy, a GFP expressing rAAV5 vector was used, showing an average of $60 \%$ positive cells. ILI $\beta$ stimulation resulted in a significant increase of TNFRI-Ig production using both constructs. However, the NFкB promoter-driven construct showed a much higher protein production compared with the CMV promoter. The same trend, although to a lesser extent, was observed using TNF $\alpha$ or LPS as a stimulus. Importantly, induced production was effectively inhibited by blocking NFKB independent of the stimulus used.

Both rat and human $\mathrm{TNF} \alpha$ were effectively neutralised by TNFRI-Ig produced by FLS after transduction with the rAAV5 vector as tested in a bioassay (figure $1 \mathrm{~B}$ ). However, $50 \%$ of the human TNF $\alpha$ was already neutralised at $2.3 \mathrm{ng} / \mathrm{ml}$ TNFRI-Ig, whereas it took $3.1 \mathrm{ng} / \mathrm{ml}$ TNFRI-Ig to neutralise $50 \%$ of rat $\mathrm{TNF} \alpha$, indicating a higher affinity of human TNFRI-Ig for human TNF $\alpha$ compared with rat TNF $\alpha$.

\section{Local delivery and expression of the TNFRI-Ig gene}

After intra-articular injection of the rAAV5 vectors, human TNFRI-Ig RNA was found in the joints treated with rAAV5.NFKB-TNFRI-Ig and rAAV5.CMV-TNFRI-Ig, but not in control vector-treated joints (figure $2 \mathrm{~A}$ ). This was quantified by real-time PCR, showing increased levels compared with controls (mean (SD) 342.30 (86.4)\% and 228.35 (16.6)\% for rAAV5.NFKB-TNFRI-Ig and rAAV5.CMV-TNFRI-Ig, respectively (figure 2B). In addition, joint sections were immunohistochemically stained to detect human TNFRI-Ig protein (figure 2C). TNFRI-Ig positive cells were observed in the synovium of animals injected with rAAV5.NFкB-TNFRI-Ig and to a lesser extent in those injected with rAAV5.CMV-TNFRI-Ig. The control group showed no staining. This was confirmed by
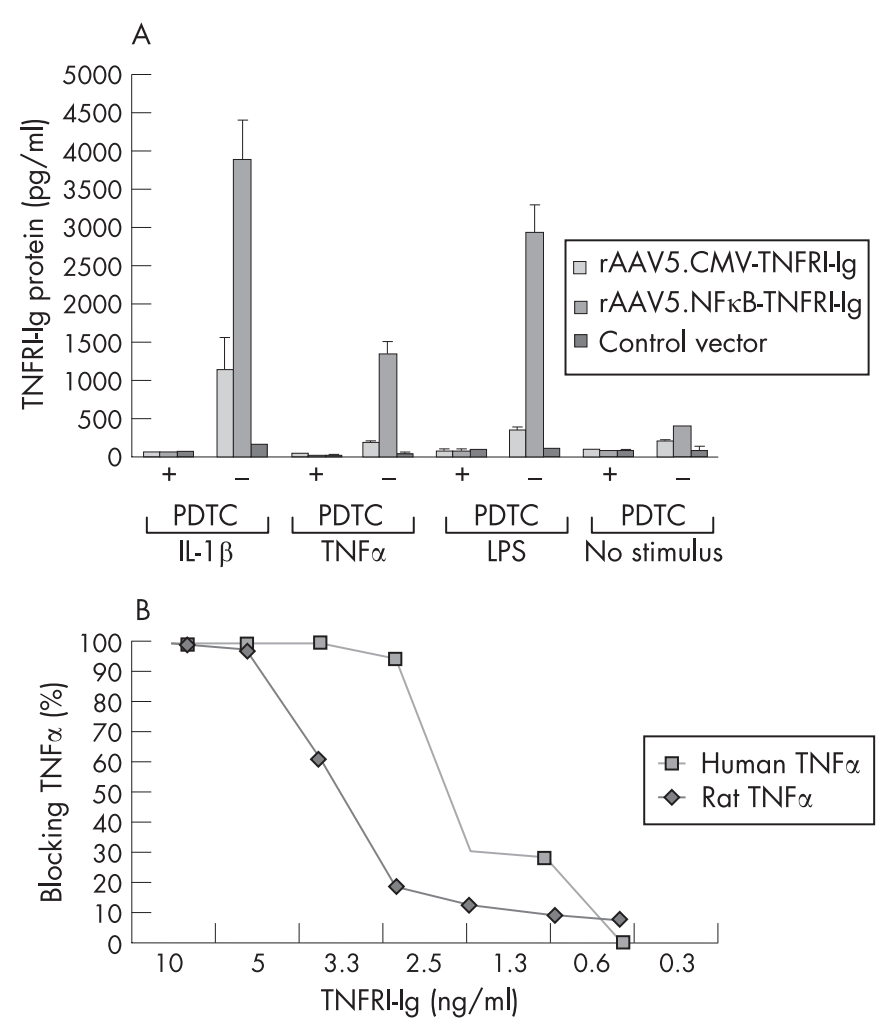

Figure 1 In vitro validation of promoter and transgene function. Fibroblast-like synoviocytes (FLS) were transduced with rAAV5 containing the NFKB.TNFRI-lg or the CMV-TNFRI-lg gene. After 24 hours, interleukin (IL) $1 \beta(100 \mathrm{ng} / \mathrm{ml})$, tumour necrosis factor (TNF) $\alpha(100 \mathrm{ng} / \mathrm{ml})$ or lipopolysaccharide (LPS; $1 \mu \mathrm{g} / \mathrm{ml}$ ) was added to the culture medium in the presence or absence of the nuclear factor kappa $B$ (NFKB) blocking agent pyrrolidinedithiocarbamate (PDTC; $200 \mu \mathrm{mol} / \mathrm{l}$ ). (A) Forty-eight hours later, the supernatants were collected and an ELISA was performed to analyse the amount of TNFRI-lg protein. The capacity of produced TNFRI-lg to bind and neutralise human and rat TNF $\alpha$ was tested in a TNF $\alpha$ bioassay. (B) The percentage of TNF $\alpha$ neutralisation by TNFRI-Ig is directly related to the percentage of the number of surviving cells and expressed as percentage of TNF $\alpha$ blocking. The presented results are performed in triplicate and are representative for two independent experiments. 


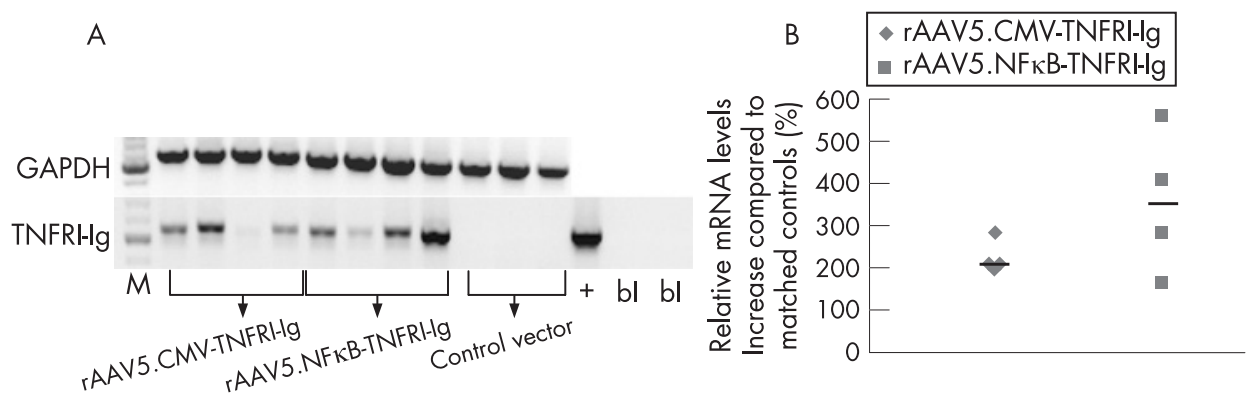

C

rAAV5.NFKB-TNFRI-Ig
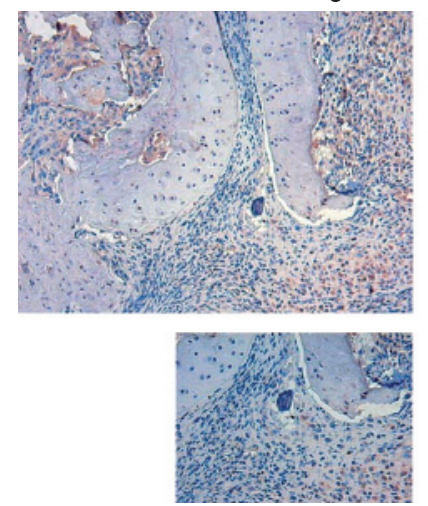

rAAV5.CMV-TNFRI-lg
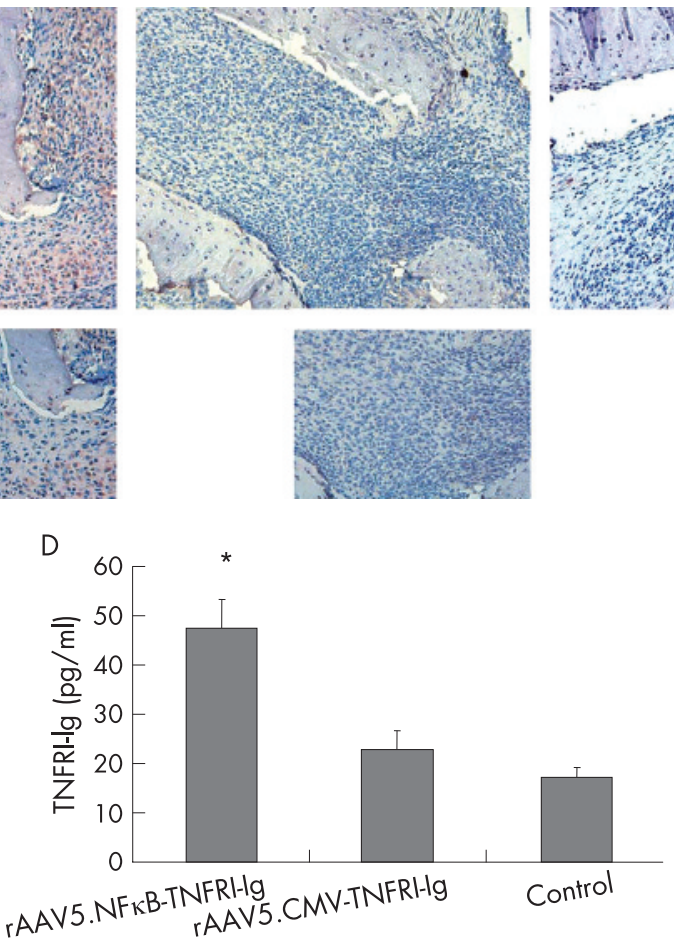

Control

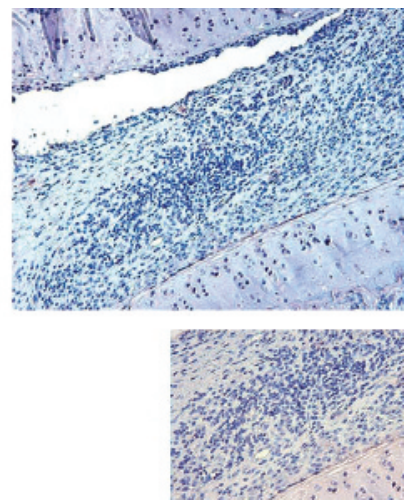

Figure 2 Human tumour necrosis factor receptor type I (TNFRI)-lg gene transcription in the ankle joints of rats with adjuvant arthritis after local recombinant adeno-associated virus ( $r A A V 5$ ) gene therapy. Total RNA was extracted from crushed joints 14 days after intra-articular injection and cDNA was synthesised. Reverse-transcriptase PCR was performed using primers specific for the human TNFRI-lg gene. Plasmid containing the human TNFRI-lg gene was used as positive control ( + ), and a no-template control as blanks (bl). (A) Rat glyceraldehyde phosphodehydrogenase (GAPDH) was used as a reference gene ( $n=4$ /group). A real-time PCR was performed to calculate the percentage TNFRI-lg upregulation. (B) Obtained threshold cycle (Ct) values were normalised to GAPDH levels and expressed as percentage increase compared with matched controls as individual data points (median). All treated animals significantly overexpressed the transgene in the joints $\left({ }^{*} p<0.05\right)(n=4 /$ group). (C) Ankle joints were embedded in paraffin wax, sectioned and immunohistochemically stained for human TNFRI-lg and counterstained with Mayer's haemalum ( $\mathrm{n}=2 / \mathrm{group}$ ). Representative pictures are shown (original magnification $100 \times$ (upper panels), $200 \times$ (lower panels)). (D) Protein was isolated from injected joints and an ELISA for TNFRI was performed. Intraarticular injection of rAAV5.NFKB-TNFRI-lg resulted in the highest levels of TNFRI-lg in joint protein isolates $(p<0.05)$, whereas the cytomegalovirus (CMV)driven construct only resulted in TNFRI-lg levels slightly above those in controls ( $n=4 /$ group).

ELISA, showing a significant increase in TNFRI-Ig production in rats treated with rAAV5.NFkB-TNFRI-Ig (47.53 (5.72) pg/ml versus 17.12 (1.98) pg/ml, $\mathrm{p}<0.05$ compared with control), whereas those treated with rAAV5.CMV-TNFRI-Ig showed a trend towards lower levels of TNFRI-Ig (22.87(3.89) pg/ml versus 17.12 (1.98) pg/ml; NS) (figure 2D).

\section{Anti-arthritic effects of locally transduced TNFRI-Ig gene} In the rats treated with rAAV5.NFKB-TNFRI-Ig, significantly less paw swelling was observed, as tested by differences in area under the curve from the day of treatment until the end of the experiment compared with controls $(p<0.05)$. There was a trend towards less paw swelling in rats treated with the rAAV5 vector containing the TNFRI-Ig gene under control of a CMV promoter, but this difference did not reach statistical significance (figure 3A). Consistent with these findings, we found a reduction in synovial inflammation only in animals injected with rAAV5.NFKB-TNFRI-Ig compared with controls (2.0 $(0.57)$ versus $3.3(0.33)$, respectively, $p<0.05$ ) (figure $3 \mathrm{~B}$ and 3C).

\section{Changes in cytokine profile after rAAV5.TNFRI-Ig gene therapy}

The joints were immunohistochemically stained to detect TNF $\alpha$, ILl $\beta$, IL6, and IL10 (figure 4A). TNF $\alpha$ levels were significantly $(\mathrm{p}<0.05)$ lower in the synovial tissue of animals treated with rAAV5.NFKB-TNFRI-Ig (0.66 (0.88)), but not in animals treated with rAAV5.CMV-TNFRI-Ig $(2(0.57))$, compared with controls $(2.33(0.88))$ (figure $4 \mathrm{~B})$. The same consistent pattern was observed for IL1 $\beta$ ( $1(0.57)$ and $3(0.58)$ versus $2.66(0.89)$ 


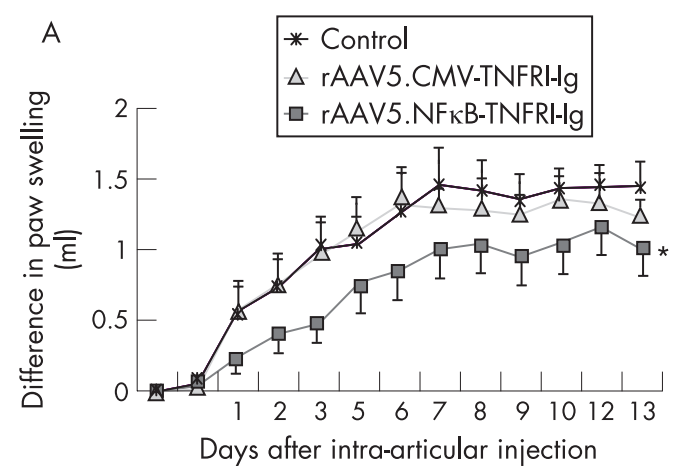

B
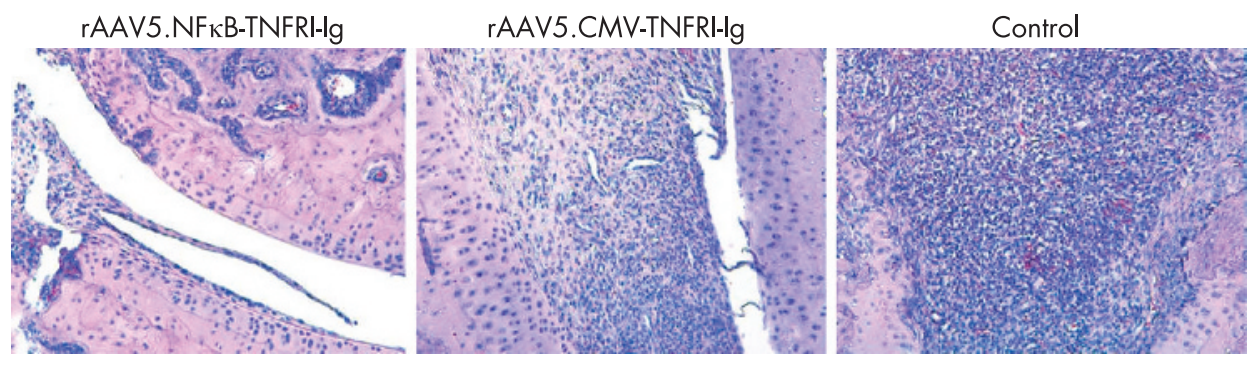

C

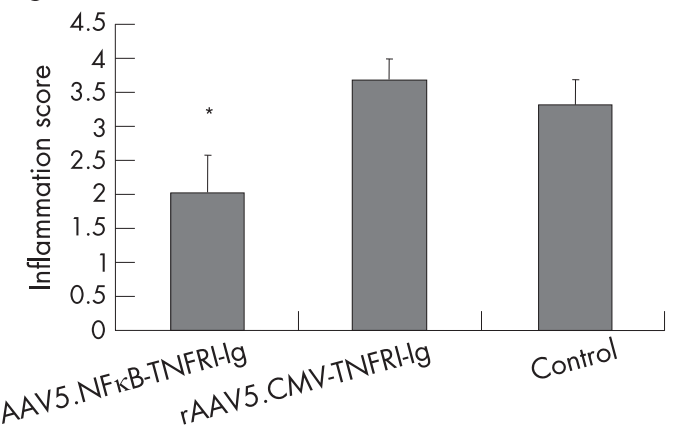

Figure 3 Effects of constitutive local TNF blockade on paw swelling and inflammation in rats with adjuvant arthritis. To evaluate the effects of rAAV5.CMVTNFRI-lg or rAAV5.NFKB-TNFRI-lg gene therapy on clinical arthritis, 10 rats per group were injected intra-articularly into the right ankle joint with the therapeutic or control vector on day 12 after arthritis induction. (A) Paw swelling was measured by water displacement plethysmometry and expressed as $\Delta$ paw swelling ( $n=10 /$ group) ( ${ }^{*} \mathrm{p}<0.05$, as tested by difference in area under the curve from the day of treatment until the end of the experiment). Results are representative of two separate experiments. (B) At the end of the experiment, joints were removed, embedded in paraffin wax and examined by routine histology. Tissue sections were stained with haematoxylin and eosin ( $n=5 /$ group) original magnification $100 \times$. (C) The tissue was evaluated using a semiquantative scoring system (0-4) for synovial hyperplasia and expressed as mean (SEM). Rats treated with rAAV5.NFkB-TNFRI-Ig displayed significantly less synovial hyperplasia (* $\mathrm{p}<0.05)$.

for rAAV5.NFKB-TNFRI-Ig and rAAV5.CMV-TNFRI-Ig compared with control) and IL6 (1.3 (0.34) and 2.33 (0.67) versus 2.67 (0.33) for rAAV5.NFkB-TNFRI-Ig and rAAV5.CMV-TNFRIIg compared with control). Interestingly, the anti-inflammatory cytokine IL10 was significantly increased in rats treated with rAAV5.NFKB-TNFRI-Ig compared with controls (4.0 (0) versus $2.33(0.33))$, whereas rAAV5.CMV-TNFRI-Ig injected animals showed no difference in IL10 levels.

\section{Biodistribution of transgene transcription after intra- articular rAAV5 injection}

At the end of experiment, organs and blood were collected to examine spreading of the virus using real time PCR. No significant copies of the transgene were found in the tissues examined. A slight increase in human TNFRI-Ig mRNA was found only in spleen and draining lymph nodes compared with control group. However, a $\Delta \mathrm{Ct}$ value of one, resulting in a twofold increase in detectable transcripts, is considered below the detection limit of this method (figure 5). In addition, no
TNFRI-Ig protein was found in plasma using a specific ELISA (data not shown).

\section{DISCUSSION}

The present study shows that intra-articular injection of a human TNFRI-Ig expressed by an rAAV5 vector with an NFKB inducible promoter in rats with adjuvant arthritis results in secreted and bioactive TNFRI-Ig, able to block TNF $\alpha$ in the injected joint, providing a therapeutic effect.

$\mathrm{TNF} \alpha$ is a key mediator in rheumatoid arthritis and systemic administration of soluble forms of its receptors has successfully entered clinical practice. ${ }^{25}{ }^{26}$ TNFRI has a higher affinity for $\mathrm{TNF} \alpha$, and plays a predominant role in the induction of cellular responses by TNF $\alpha$. Studies with TNFRI knockout mice have shown that TNF signalling through TNFRI controls the severity of experimental arthritis. ${ }^{27}$ In addition, treatment with soluble TNFRI was effective in a rat model of arthritis ${ }^{28}$ as well as in mouse models of sepsis ${ }^{29}$ and uveitis. ${ }^{30}$ Results in clinical trials with patients with rheumatoid arthritis treated with a 
A

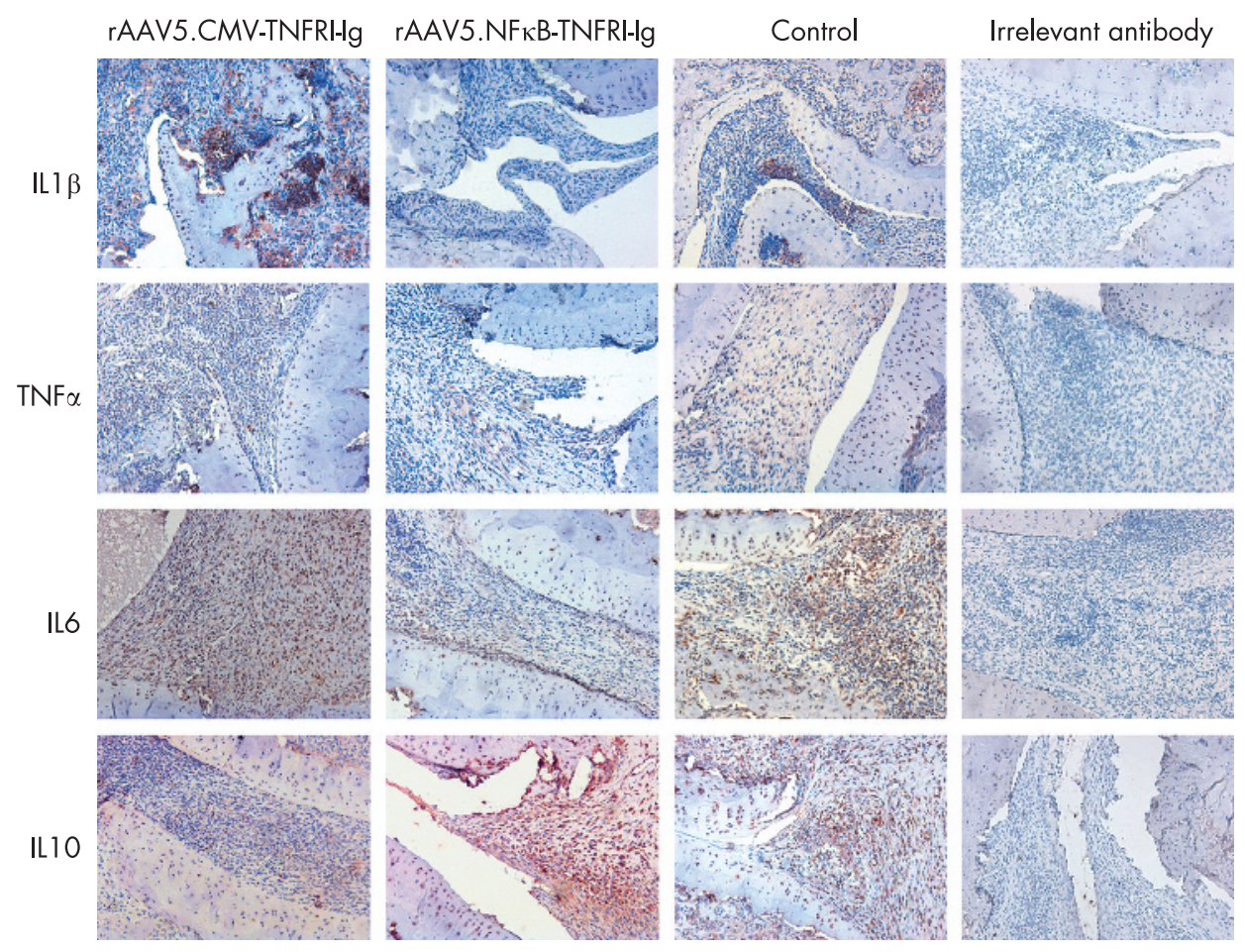

B

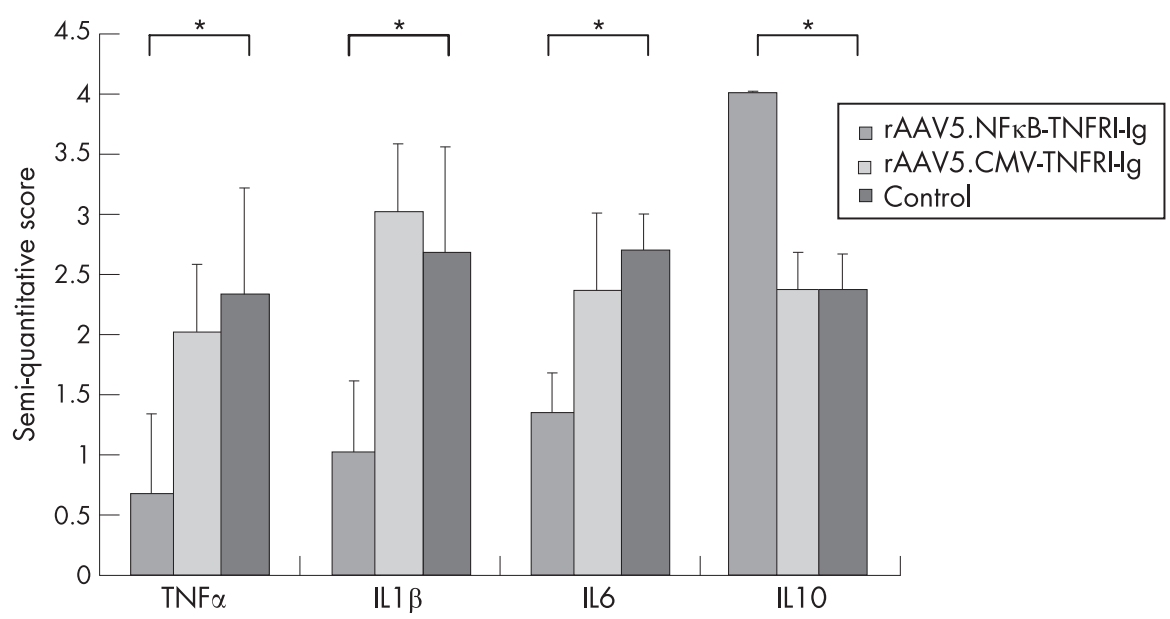

Figure 4 Cytokine levels in rat synovial tissue. At the end of the experiment, ankle joints were collected, embedded in paraffin wax and immunohistochemically stained with anti-rat interleukin (IL) $1 \beta$ IL6 and IL10 and tumour necrosis factor (TNF) $\alpha$, antibodies and counterstained with Mayer's haemalum. An irrelevant antibody was used as control. (A) Representative pictures are shown (original magnification 100 $\times$ ). (B) The images were semiquantitatively scored $(0-4)$ by two independent observers $\left({ }^{*} p<0.05\right)$. Values are expressed as mean $(S E M)(n=5 / g r o u p)$.

TNFRI:Fc fusion protein were also encouraging, although variable. This could be explained by the formation of nonneutralising antibodies and the short half-life of the compound used. ${ }^{31}$ In addition, the systemic dosages might have failed to achieve intra-articular therapeutic levels.

Local overexpression of this TNF inhibitor via gene therapy might maximise the therapeutic potential. Previous work using the TNFRI-Ig gene from a plasmid electrotransferred into muscle at the onset of the disease showed a beneficial effect in murine CIA. ${ }^{12}$ Although this would prevent multiple injections in patients, it does not have the advantage of local treatment. Using a similar gene expressed from an adenoviral construct, a moderate, transient effect was reported after intra-articular injection in mice, ${ }^{32}{ }^{33}$ rats $^{33}$ and rabbits. ${ }^{34}$ An immune response to the adenoviral vector was identified as a potential cause for this short-lived effect. To overcome this problem, the less immunogenic rAAV2 was used, coding for the monomeric form of the TNFRI, resulting in inhibition of arthritis after intraarticular injection in TNF $\alpha$ transgenic mice. ${ }^{8}$ The monomeric form of the receptor, however, only binds one subunit of the $\mathrm{TNF} \alpha$ trimer, hence only weakly prevents the action of this cytokine. ${ }^{35}$ In addition, monomeric forms are rapidly cleared from the circulation.

We combined the potency of the TNFRI-Ig gene with the superior efficacy of an rAAV5 vector driven by an NFKB and CMV promoter, and evaluated the therapeutic effects in an animal model of rheumatoid arthritis. The promoter function and biological activity of TNFRI-Ig was confirmed in vitro as 


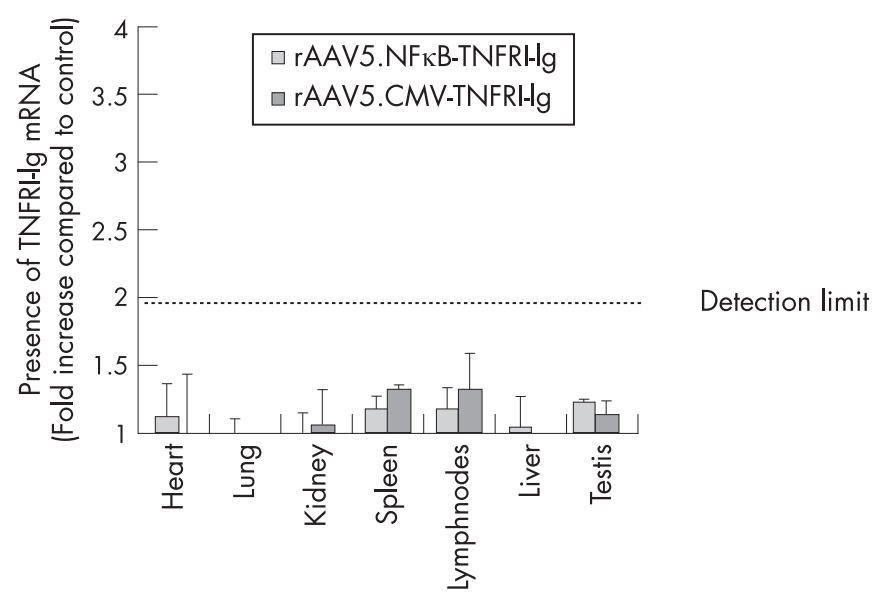

Figure 5 Biodistribution of transgene transcription after intra-articular injection. To assess the presence of the transgene, heart, lung, kidney, spleen, draining lymph nodes, liver, and testis were excised and homogenised 14 days after intra-articular injection. RNA was isolated and cDNA was synthesised ( $n=5$ /group). Real-time PCR was performed using transgene specific primers. The resulting threshold cycle $(\mathrm{Ct})$ values were normalised to glyceraldehyde phosphodehydrogenase (GAPDH) levels and expressed as fold increase compared with control (mean (SEM)).

well as in vivo. One single injection of rAAV5 containing the gene for TNFRI-Ig into arthritic joints of rats resulted in reduction of arthritis severity, consistent with the observed neutralisation of intra-articular TNF $\alpha$. In line with the effect on paw swelling, a significant reduction in synovial hyperplasia was observed accompanied by a decrease in pro-inflammatory cytokines such as TNF $\alpha$, IL1 $\beta$ and IL6 and an increase in the anti-inflammatory cytokine IL10, thereby disengaging the cytokine cascade that leads to synovial inflammation. Importantly, no significant transgene transcripts were detected outside the joints, adding to the safety profile of this local approach.

Despite the severity of the animal model used, adjuvant arthritis in rats, a clear clinical effect was observed, indicating the effectiveness of local gene therapy using this gene construct. In a clinical setting, an even more pronounced effect might be expected, owing to the higher affinity we observed for human $\mathrm{TNF} \alpha$ compared with rat TNF $\alpha$. Although both CMV and NFKB promoter driven constructs were proven bioactive in vitro and in vivo, only the transgene under control of the disease inducible promoter resulted in a significant therapeutic effect. The exact mechanism for this remains unclear, but it could involve the "on demand" high TNFRI-Ig production induced when pro-inflammatory factors are upregulated. In fact, we found higher production of the therapeutic protein in vitro after stimulation of the NFKB-responsive promoter, and this was NFKB-dependent. The difference between TNFRI-Ig protein production as detected by the ELISA after ILI $\beta$ or LPS and TNF $\alpha$ stimulation could partly be explained by the fact that TNFRI-Ig protein secreted into the culture medium after TNF $\alpha$ stimulation can bind exogeneous added TNF $\alpha$ present in the medium and neutralise its activity. The ELISA used can only detect free and not bound TNFRI. In addition, we also observed lower levels of both TNFRI-Ig mRNA and protein in vivo using the CMV-driven construct compared with the NFKB-driven construct. Looking at TNFRI-Ig mRNA levels, the variation in animals treated with rAAV5.CMV-TNFRI-Ig is minimal compared with those treated with rAAV5.NFkB. This might reflect the disease-induced transcription during the variable course of arthritis in vivo using the NFKB promoter. These are of course endpoint measurements, giving little information about the kinetics of production during the course of disease.
In conclusion, this work supports the feasibility of local gene therapy using an rAAV5 vector to deliver a therapeutic gene directly to the inflamed joint. Additionally, disease-regulated transgene expression for physiologically responsive gene therapy might be feasible and could contribute to the safety and effectiveness of the gene-therapy approach. Thus, this study provides the rationale for further research towards clinical development of rAAV5.NFkB-TNFRI-Ig intra-articular gene therapy.

\section{ACKNOWLEDGEMENTS}

This research was supported by the European Community's FP6 funding. This publication reflects only the author's views. The European Community is not liable for any use that may be made of the information herein.

\section{Authors' affiliations}

J Adriaansen, M J B M Vervoordeldonk, P P Tak, Division of Clinical Immunology and Rheumatology, Academic Medical Center, University of Amsterdam, Amsterdam, the Netherlands

M Khoury, F Apparailly, C Jorgensen, Inserm, U 475, F-34197

Montpellier, France

M Khoury, F Apparailly, C Jorgensen, Université Montpellier1, UFR de Médecine, F-34000 Montpellier, France

C J de Cortie, F J Fallaux, M J B M Vervoordeldonk, P P Tak, Arthrogen BV, Amsterdam, the Netherlands

P Bigey, D Scherman, Inserm, U 640, F-75006 Paris, France; CNRS, UMR8151, F-75006 Paris, FranceUniversité Paris Descartes, Faculté de Pharmacie, Laboratoire de Pharmacologie Chimique et Génétique, F75270 Paris, France; and Ecole Nationale Supérieure de Chimie de Paris, F-75005 Paris, France

D J Gould, Y Chernajovsky, Bone and Joint Research Unit, William Harvey Research Institute, Barts and The London Queen Mary's School of Medicine and Dentistry, University of London, London, UK

C Jorgensen, Service Clinique d'Immuno-Rhumatologie, CHU Lapeyronie, F-34295 Montpellier, France

The first two authors contributed equally to this work.

\section{REFERENCES}

1 Tak PP, Bresnihan B. The pathogenesis and prevention of joint damage in rheumatoid arthritis: advances from synovial biopsy and tissue analysis. Arthritis Rheum 2000;43:2619-33

2 Bathon JM, Martin RW, Fleischmann RM, Tesser JR, Schiff MH, Keystone EC, et al. A comparison of etanercept and methotrexate in patients with early rheumatoid arthritis. N Engl J Med 2000;343:1586-93.

3 Lipsky PE, van der Heijde DM, St Clair EW, Furst DE, Breedveld FC, Kalden JR, et al. Infliximab and methotrexate in the treatment of rheumatoid arthritis. AntiTumor Necrosis Factor Trial in Rheumatoid Arthritis with Concomitant Therapy Study Group. N Engl J Med 2000;343:1594-602.

4 Gomez-Reino JJ, Carmona L, Valverde VR, Mola EM, Montero MD. Treatment of rheumatoid arthritis with tumor necrosis factor inhibitors may predispose to significant increase in tuberculosis risk: a multicenter active-surveillance report. Arthritis Rheum 2003;48:2122-7.

5 Adriaansen J, Vervoordeldonk M, Tak PP. Gene therapy as a therapeutic approach for the treatment of rheumatoid arthritis: innovative vectors and therapeutic genes. Rheumatology (Oxford) 2006;45:656-68.

6 Grieger JC, Samulski RJ. Adeno-associated virus as a gene therapy vector: vector development, production and clinical applications. Adv Biochem Eng Biotechnol 2005;99: 119-45.

7 Rabinowitz JE, Samulski J. Adeno-associated virus expression systems for gene transfer. Curr Opin Biotechnol 1998;9:470-5.

8 Zhang HG, Xie J, Yang P, Wang Y, Xu L, Liu D, et al. Adeno-associated virus production of soluble tumor necrosis factor receptor neutralizes tumor necrosis factor alpha and reduces arthritis. Hum Gene Ther 2000;11:2431-42.

9 Chan JM, Villarreal G, Jin WW, Stepan T, Burstein H, Wahl SM. Intraarticular gene transfer of TNFR:Fc suppresses experimental arthritis with reduced systemic distribution of the gene product. Mol Ther 2002;6:727-36.

10 Adriaansen J, Tas SW, Klarenbeek PL, Bakker AC, Apparailly F, Firestein GS, et al. Enhanced gene transfer to arthritic joints using adeno-associated virus type 5 : implications for intra-articular gene therapy. Ann Rheum Dis 2005;64:1677-84.

11 Apparailly F, Khoury M, Vervoordeldonk MJ, Adriaansen J, Gicquel E, Perez N, et al. Adeno-associated virus pseudotype 5 vector improves gene transfer in arthritic joints. Hum Gene Ther 2005; 16:426-34.

12 Bloquel C, Bessis N, Boissier MC, Scherman D, Bigey P. Gene therapy of collagen-induced arthritis by electrotransfer of human tumor necrosis factoralpha soluble receptor I variants. Hum Gene Ther 2004;15:189-201. 
13 Peppel K, Crawford D, Beutler B. A tumor necrosis factor (TNF) receptor-lgG heavy chain chimeric protein as a bivalent antagonist of TNF activity. J Exp Med $1991 ; 174: 1483-9$.

14 Xiao X, Li J, Samulski RJ. Production of high-titer recombinant adeno-associated virus vectors in the absence of helper adenovirus. J Virol 1998;72:2224-32.

15 Fromes Y, Salmon A, Wang X, Collin H, Rouche A, Hagege A, et al. Gene delivery to the myocardium by intrapericardial injection. Gene Ther 1999;6:683-8.

16 van Holten J, Reedquist K, Sattonet-Roche P, Smeets TJ, Plater-Zyberk C, Vervoordeldonk MJ, et al. Treatment with recombinant interferon-beta reduces inflammation and slows cartilage destruction in the collagen-induced arthritis model of rheumatoid arthritis. Arthritis Res Ther 2004;6:R239-49.

17 Schreck R, Meier B, Mannel DN, Droge W, Baeverle PA. Dithiocarbamates as potent inhibitors of nuclear factor kappa $B$ activation in intact cells. J Exp Med 1992;175:1181-94.

18 Eskandari MK, Nguyen DT, Kunkel SL, Remick DG. WEHI 164 subclone 13 assay for TNF: sensitivity, specificity, and reliability. Immunol Invest 1990; 19:69-79.

19 Tak PP, Gerlag DM, Aupperle KR, van de Geest DA, Overbeek M, Bennett BL, et al. Inhibitor of nuclear factor kappaB kinase beta is a key regulator of synovial inflammation. Arthritis Rheum 2001;44:1897-907.

20 Nguyen KH, Boyle DL, McCormack JE, Chada S, Jolly DJ, Firestein GS. Direct synovial gene transfer with retroviral vectors in rat adjuvant arthritis. J Rheumatol 1998;25:1118-25.

21 Vandesompele J, De Preter K, Pattyn F, Poppe B, Van Roy N, De Paepe A, et al. Accurate normalization of real-time quantitative RT-PCR data by geometric averaging of multiple internal control genes. Genome Biol 2002;3:RESEARCH0034.

22 Joosten LA, Helsen MM, Saxne T, van De Loo FA, Heinegard D, van Den Berg WB. IL1 alpha beta blockade prevents cartilage and bone destruction in murine type II collagen-induced arthritis, whereas TNF-alpha blockade only ameliorates joint inflammation. J Immunol 1999;163:5049-55.

23 Adriaansen J, Kuhlman RR, Holten JV, Kaynor C, Vervoordeldonk MJ, Tak PP. Intraarticular interferon-beta gene therapy ameliorates adjuvant arthritis in rats. Hum Gene Ther 2006;17:996-8.

24 Tak PP, Thurkow EW, Daha MR, Kluin PM, Smeets TJ, Meinders AE, et al. Expression of adhesion molecules in early rheumatoid synovial tissue. Clin Immunol Immunopathol 1995;77:236-42.
25 Moreland LW. Inhibitors of tumor necrosis factor: new treatment options for rheumatoid arthritis. Cleve Clin J Med 1999;66:367-74.

26 Smith CA, Davis T, Anderson D, Solam L, Beckmann MP, Jerzy R, et al. A receptor for tumor necrosis factor defines an unusual family of cellular and viral proteins. Science 1990;248:1019-23.

27 Zhao YX, Zhang H, Chiu B, Payne U, Inman RD. Tumor necrosis factor receptor p55 controls the severity of arthritis in experimental Yersinia enterocolitica infection. Arthritis Rheum 1999;42:1662-72.

28 McComb J, Gould T, Chlipala E, Sennelo G, Frazier J, Kieft G, et al. Antiarthritic activity of soluble tumor necrosis factor receptor type I forms in adjuvant arthritis: correlation of plasma levels with efficacy. J Rheumatol 1999;26:1347-51.

29 Evans TJ, Moyes D, Carpenter A, Martin R, Loetscher H, Lesslauer W, et al. Protective effect of 55- but not 75-kD soluble tumor necrosis factor receptorimmunoglobulin $\mathrm{G}$ fusion proteins in an animal model of gram-negative sepsis. J Exp Med 1994;180:2173-9

30 Robertson M, Liversidge J, Forrester JV, Dick AD. Neutralizing tumor necrosis factor-alpha activity suppresses activation of infiltrating macrophages in experimental autoimmune uveoretinitis. Invest Ophthalmol Vis Sci 2003;44:3034-41.

31 Furst DE, Weisman $M$, Paulus HE, Bulpitt K, Weinblatt $M$, Polisson R, et al. Intravenous human recombinant tumor necrosis factor receptor $\mathrm{p} 55-\mathrm{Fc} \operatorname{lgG} 1$ fusion protein, Ro 45-2081 (lenercept): results of a dose-finding study in rheumatoid arthritis. J Rheumatol 2003;30:2123-6.

32 Quattrocchi E, Walmsley M, Browne K, Williams RO, Marinova-Mutafchieva L, Buurman W, et al. Paradoxical effects of adenovirus-mediated blockade of TNF activity in murine collagen-induced arthritis. J Immunol 1999;163:1000-9.

33 Le CH, Nicolson AG, Morales A, Sewell KL. Suppression of collagen-induced arthritis through adenovirus-mediated transfer of a modified tumor necrosis factor alpha receptor gene. Arthritis Rheum 1997;40:1662-9.

34 Ghivizzani SC, Lechman ER, Kang R, Tio C, Kolls J, Evans CH, et al. Direct adenovirus-mediated gene transfer of interleukin 1 and tumor necrosis factor alpha soluble receptors to rabbit knees with experimental arthritis has local and distal anti-arthritic effects. Proc Natl Acad Sci U S A 1998;95:4613-18.

35 Adam D, Kessler U, Kronke M. Cross-linking of the p55 tumor necrosis factor receptor cytoplasmic domain by a dimeric ligand induces nuclear factor-kappa $B$ and mediates cell death. J Biol Chem 1995;270:17482-7.

\section{bmjupdates+}

bmjupdates+ is a unique and free alerting service, designed to keep you up to date with the medical literature that is truly important to your practice.

bmjupdates+ will alert you to important new research and will provide you with the best new evidence concerning important advances in health care, tailored to your medical interests and time demands.

\section{Where does the information come from?}

bmjupdates+ applies an expert critical appraisal filter to over 100 top medical journals A panel of over 2000 physicians find the few 'must read' studies for each area of clinical interest

Sign up to receive your tailored email alerts, searching access and more...

www.bmjupdates.com 